\title{
Discourses, Power Negotiations and Indigenous Political Organization in Forest Partnerships: The Case of Selva de Matavén, Colombia
}

\author{
Eloisa Berman Arévalo • Mirjam A. F. Ros-Tonen
}

Published online: 16 July 2009

(C) The Author(s) 2009. This article is published with open access at Springerlink.com

\begin{abstract}
While much research on forest partnerships hitherto has been focused mainly on the drivers behind their formation, the kind of actors and deals involved, and the factors that promote or hinder their success, much less attention has been paid to the dynamic relationships and processes inherent in these partnerships. Based on the study of a partnership process in an indigenous reservation in Colombian Amazonia covering a variety of projects, this paper seeks to fill part of this lacuna by analyzing the partnership as a dynamic 'discursive battlefield,' in which objectives and actions are being constantly negotiated. Actors in the Matavén partnership strategically incorporate discursive elements in order to pursue their own interests while also endorsing those that ensure the continuation of collaboration. We conclude that discourses are embedded in partnership micro-politics. On the one hand, discursive shifts occur as a reflection of power balances at given moments. On the other hand, discourses constitute indispensable resources with the potential to both enhance individual actor's negotiating power and to create opportunities for compromise. Within an ongoing discursive tension between 'conservation' and 'indigenous autonomy,'
\end{abstract}

\footnotetext{
E. Berman Arévalo

Colombian National Parks System,

Bogotá, Colombia

e-mail: eloisaberman@gmail.com
}

M. A. F. Ros-Tonen $(\bowtie)$

Amsterdam Institute for Metropolitan and International

Development Studies (AMIDSt), University of Amsterdam,

Nieuwe Prinsengracht 130 ,

1018 VZ Amsterdam, The Netherlands

e-mail: m.a.f.ros-tonen@uva.nl flexible notions such as 'territorial ordering' prove to be successful in allowing space for manoeuvre and granting conceptual coherence to shifts occurring 'on the ground.'

Keywords Multi-sector partnerships · Environmental discourses $\cdot$ Indigenous political organization .

Territorial ordering $\cdot$ Colombian Amazonia

\section{Introduction}

Indigenous peoples ${ }^{1}$ have become key players in global efforts for environmental protection (Conklin 1997; Escobar 1998; Ulloa 2004: 97). Linking notions of territory, autonomy, tradition and conservation (Jackson and Warren 2005; Offen 2003; Van Cott 2001), indigenous movements have borrowed and transformed elements from global environmental discourses, incorporating them into the framing of their struggles for self-determination (Jackson and Warren 2005; Ulloa 2004). As a result of these struggles, democratic transformations and state reforms in Latin America have incorporated the recognition of indigenous collective rights (Assies 2000: 3; Van Cott 2001), often integrating indigenous self-determination, environmental protection and administrative decentralization (Brackelaire 2005: 46). Consequentially, new forms of forest governance are emerging. In Colombia, the Political Constitution of 1991 (CPC-91, República de Colombia 1991) granted semi-autonomous status to indigenous territories, which today constitute $25 \%$ of the national

\footnotetext{
${ }^{1}$ Indigenous peoples are understood according to the widely-used definition adopted by the United Nations: Martinez Cobo 1986, 5: para. 379 .
} 
territory and more than $80 \%$ of its forest areas, recognized under the figure of resguardos ${ }^{2}$ (Van der Hammen 2003: 7).

Devolution of land and public functions to indigenous communities has resulted in new forms of indigenous government that are supported by NGOs, state organizations and international donors through multi-sector partnerships (MSPs; Ros-Tonen et al. 2007: 16). These partnerships are often projects for conservation and sustainable development (Ros-Tonen et al. 2007; Dove 2006), while also providing technical, political and financial support to indigenous territorial and political processes (Offen 2003; Perreault 2001, 2003; Andolina et al. 2005). MSPs have thus become dynamic arenas where the demands for forest conservation and indigenous political re-organization (Nagel and Snipp 1993) are constantly negotiated and re-prioritized.

This article discusses the case of Selva de Matavén, a two million hectare indigenous resguardo in Colombian Amazonia, where a partnership process has been taking place for the past ten years between NGOs, government institutions and indigenous authorities organized under a local Association. Its objectives have integrated territorial protection, natural resource management and consolidation of indigenous self-government.

Discourses - and the adoption of particular framing concepts - play a fundamental role in both shaping and reflecting the dynamics of MSP negotiations. Indeed, the partnership process can be conceived as a 'discursive battlefield' where discourses reflect power balances at given moments and act as resources strategically used by actors to pursue their interests and give conceptual coherence to de facto shifts occurring in practice. This paper examines the internal dynamics and evolution of this 'discursive battlefield' by offering a nuanced 'story' of the development of partnership discourses, focusing on the roles and strategies of intermediary-level actors, on the power relationships between them, and on the outcomes of this process in terms of discursive shifts and consequential shifts in partnership/project implementation.

\section{Selva de Matavén: The Place, the People and the Partnership}

The area known today as Selva de Matavén refers to a territory of $1,849,613$ ha, legally recognized as collective indigenous property under the title of Great Resguardo of

\footnotetext{
$\overline{2}$ The indigenous resguardo is a legal figure that represents indigenous territories with collective property titles recognized by the State. Basic characteristics include that internal management and government correspond to indigenous local authorities, and that they are inalienable, imprescriptible and non-seizable. It is a legal and sociopolitical institution for the autonomous management of indigenous territories and affairs (Rodríguez 2004).
}

Selva de Matavén (INCORA 2003). It is located in a transitional area between the Colombian Orinoquia and Amazonia Regions, along the Colombian-Venezuelan border (Fig. 1). Selva de Matavén constitutes a zone of 'rapid environmental transition' between the Amazonian rainforest to the south, the savannahs of the western Orinoco watershed and Guiana Shield formations (Hernández Camacho et al. 1992). It is therefore a highly heterogeneous area, covered by a mosaic of habitats and ecosystems. Besides several forest types, there are notable savannah enclaves in the northern and north-eastern portions, enormous, pre-Cambrian rocks known as inselbergs along the Orinoco, and extensive flood lands in the Guaviare River to the south (Fig. 1).

With traditional settlement histories linked to these different biogeographical areas, Matavén includes six different ethnic groups: Sikuani, Piaroa, Puinave, Piapoco, Curripaco and Cubeo. The indigenous population is approximately 12,052, living in 149 communities (Programa Amazónico 2004). There are additionally approximately 120 small campesino farms, with a population not above 400 .

Zones with distinct socio-cultural, economic and ecological characteristics are defined by the resguardo's largest rivers - the Vichada to the north, the Orinoco to the east, and the Guaviare and Amanavén to the south (Fig. 1). and are marked by the specific dynamics of each of the resguardo's borderlands.

Until the creation of the Great Resguardo of Selva de Matavén in 2003, the area was divided in 16 small resguardos titled between 1984 and 1987. These created a belt of legal protection around the untitled center, which was open on its western flank. In the late 1990s, the need to protect the central area was recognized by indigenous leaders and the NGO Etnollano ${ }^{3}$, in the context of community-based development projects that had been taking place since the mid-1980s. The Matavén initiative analyzed here was 'launched' by the Etnollano Foundation, with the formation of a MSP for the protection of the central area of Matavén in the late 1990s and continues to involve a wide range of organizations interested in 'conservation and development' (Table 1). An Administrative Support Group (GIA) was created in 1998 to coordinate actions and project proposals. An official form of indigenous government representing all ethnic groups and previous resguardos was created in 2001, the Associ-

\footnotetext{
$\overline{3}$ The Etnollano Foundation was established in 1984 as a non-profit organization, with the stated mission "to promote and improve communities' quality of life by applying scientific research to designing, adapting, implementing and evaluating programs in the areas of health, education and social and economic improvement that can strengthen the cultural assets of those communities and promote their independent and sustainable development in favor of biodiversity conservation" (Etnollano 2000, unpublished).
} 
Fig. 1 Great Resguardo of Selva de Matavén indicating the original resguardos and Heart of Matavén
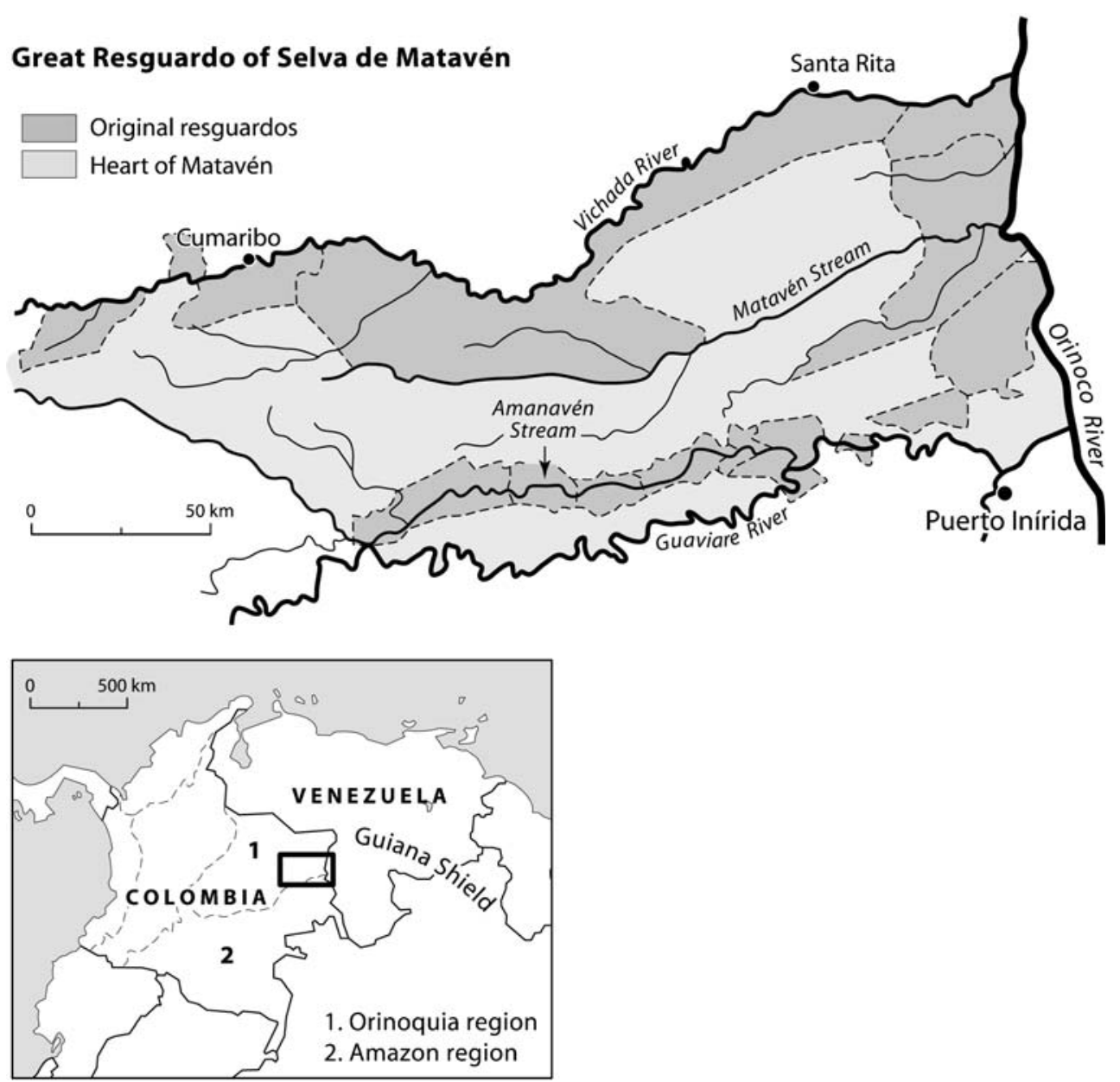

ation of Cabildos and Traditional Authorities of Matavén (ACATISEMA). As the official 'indigenous voice' among partnership actors, ACATISEMA has been increasingly influential in determining partnership discourses, goals, composition and projects. As a result, the Matavén process cannot be strictly defined as a partnership for conservation or forest management alone. In fact, the partnership process constitutes a 'discursive battlefield' in which the framing of the process is constantly shifting as the outcome of dynamic power relations between participating actors.

\section{Theoretical Framework}

\section{Partnerships}

Here we treat partnerships as "more or less formal arrangements between two or more parties from various sectors (government, civil society and/or private sector) around (at least partly) shared goals, in the expectation that each party will gain from the arrangement" (Ros-Tonen et al. 2007, p. 5). Depending on the kinds of actors involved, partnerships can be classified as public-private partner- ships, company-community partnerships, NGO-community partnerships or multi-sector partnerships (Ibid., p. 5-7). We conceive the Matavén initiative as an MSP, given the involvement of actors from multiple sectors (government, civil society, indigenous communities) and scales.

Partnerships differ from related concepts like alliances, coalitions and networks mainly in terms of formality, stability and orientation. According to Scholz (2005) alliances evolve around a common activity focusing on a specific objective and dissolve once the objective has been attained. On the other hand, in her study of a campaign against a paper mill in Honduras, Van den Hombergh (2004) uses the term coalition, while employing the term alliance for longer-term cooperation in primarily political projects. Used in this sense, alliances compare to partnerships in their long-term orientation, but differ from them in excluding the government sector, their strict political orientation and - in the case of forest partnerships - the exclusion of management objectives. Networks are larger and more loosely organized than partnerships, while focusing generally on the exchange of information and experiences (Colchester et al. 2003; Scholz 2005) rather than on common undertakings. 


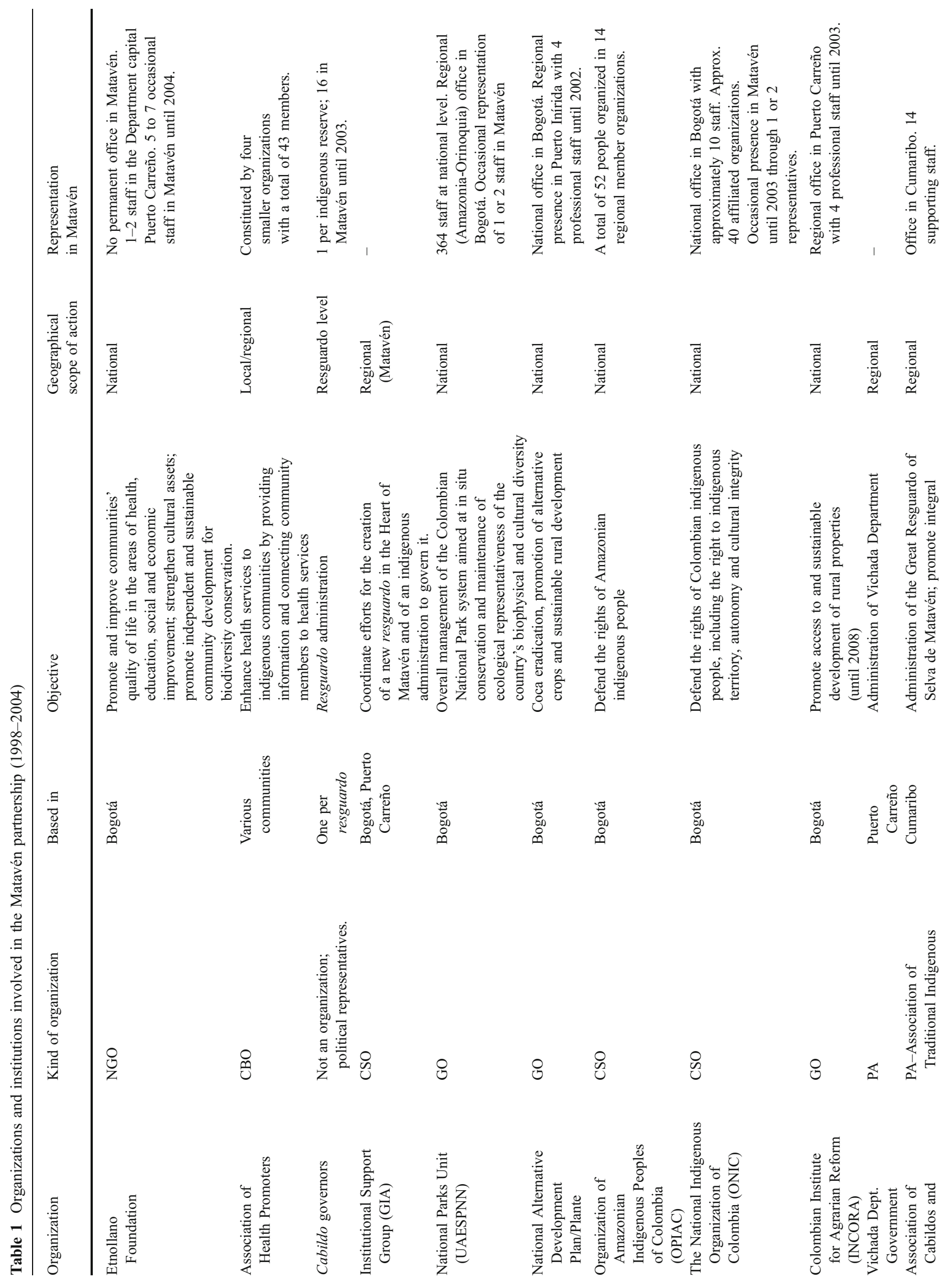




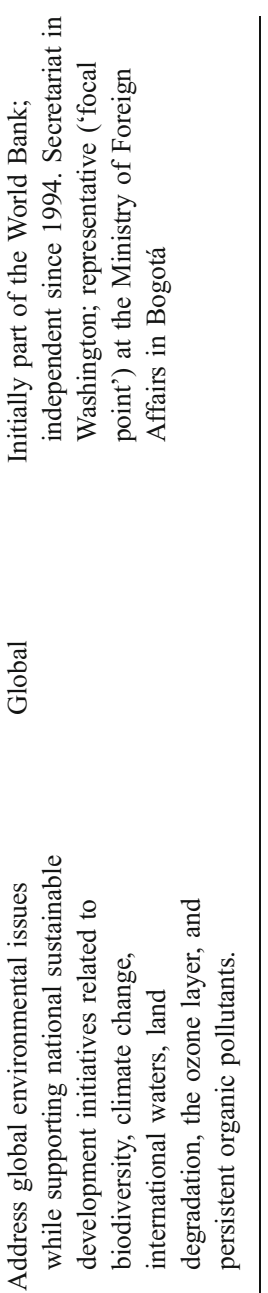

Partnerships integrating environmental and local development objectives have been advocated in development policy circles as an effective response to decentralization and devolution and the corresponding increase in the number of relevant actors in environmental governance (Fisher et al. 2005; Ros-Tonen et al. 2007; Glasbergen et al. 2007; Ros-Tonen et al. 2008). They are seen as a way of pooling resources and acting upon complex socioenvironmental problems that cross traditional political and agency boundaries (Fisher et al. 2005), and as a way to enhance 'good governance' and sustainable development and to integrate social justice and environmental agendas (Ros-Tonen et al. 2007). The United Nations Permanent Forum on Indigenous Issues (UNPFII) strongly advocates partnerships between development actors and indigenous peoples, based on the need to engage the latter in increasing trends towards 'participatory governance' (UNPFII 2005).

The "warm and positive connotation" (Ros-Tonen et al. 2007, p.5) of the partnership concept led to its ready incorporation in mainstream development and conservation thinking. However, today it is recognized that the term may mask severe power asymmetries and exploitative relations (Ibid., p. 5). Indeed, much of the literature on conservationoriented partnerships engaging indigenous peoples includes sharp critiques on 'top-down' conservation initiatives disguised under the rhetoric of 'partnerships,' 'participation' and 'integrated conservation and development' (Colchester 1996; Chapin 2004; Chernela 2005). Risks inherent in partnership relations generally result from the failure to overcome power imbalances and to reconcile diverging interests. Challenges include the exclusion of crucial social actors (Colchester et al. 2003; Scholz 2005; Van den Hombergh 2004, 2007; Rival 2007; Finley-Brook 2007; Ros-Tonen et al. 2008), negation of social (as well as ecological) dynamism and unpredictability (Fairhead and Leach 2003), and adverse effects on local governance structures (Brook 2005; Rosendo 2007), among others. Bryant (2002, p.286) frames the analysis in terms of Foucauldian 'governmentality,' arguing that conservation agendas pursue indigenous peoples' internalization of state control.

Despite the growing body of literature aiming to unravel the complexities and challenges of collaborative initiatives, research on forest partnerships hitherto has been focused mainly on the drivers behind their formation, the kinds of actors and deals involved, and the factors that promote or hinder their success, paying much less attention to their inherent dynamic relationships, negotiations and decision-making processes.

Partnership Discourses and Framing

To analyze the framing process in the Matavén initiative, we combine theoretical and analytical approaches in political ecology, an argumentative approach to discourse 
analysis (Hajer 1995), and recent works in the 'ethnography of development' (Mosse 2004, 2005). Political ecology provides the basis for the analysis of discourses about the environment and its actors. Understood broadly as a "shared meaning of a phenomenon" (Adger et al. 2001, p. 683), discourses are conceived as social constructions and as the result of negotiations imbued with power (Brosius 1999; Adger et al. 2001). In other words, embedded in language (narratives and storylines), discourses determine how particular groups perceive and interpret environmental and social problems, the actors and power relationships involved, and the appropriate solutions (Adger et al. 2001; Dryzek 2005). Moreover, attention to key actors, their interests and the negotiations between them is founded in an actor-based approach in political ecology (Bryant and Bailey 1997), useful because of its applicability to multi-scale, multi-sector research problems (Brook 2005).

In this paper, we focus not on discourses on socioenvironmental problems, but on the discourses and framing strategies of the institutional interventions aimed at tackling them. We follow Mosse's (2005) assertion that the question in the new ethnography of development "is not whether but how development projects work, not whether a project succeeds but how success is produced" (Ibid., p.8). Similarly, we focus on the dynamic, relational process through which particular framings and discourse elements are (re)introduced into partnership decision-making arenas, and strategically seized, re-interpreted, reproduced or ignored under particular circumstances and in particular scenarios. This corresponds to an argumentative approach to discourse analysis and environmental politics (Hajer 1995) which considers actors as actively involved in the production, reproduction and transformation of discourse (Ibid, p.55), and politics as a struggle in which "actors try to secure support for their definition of reality" (Ibid., p.59). From this perspective, framing is conceived as a flexible and adaptive process where actors use diverse (and sometimes contradictory) representations to reach a variety of audiences, constructing and developing frames 'in different directions,' in response to political opportunities or new possibilities for alliance (Van den Hombergh 2004, p. 49).

\section{Methods}

Research was undertaken during three years of one of the authors' involvement in the area as a practitioner for the National Parks Unit. Data analyzed encompasses a period from 1998 to 2004 .

Qualitative methods were used, including participant observation, open interviews, semi-structured interviews and analysis of institutional documents. Data analysis combined ethnographic narratives, open coding and categorizing and actor-centered discourse analysis. Three main bodies of data were used: field notes taken during visits and workshops in 2003, 2004, 2005 and May 2007; semistructured and open interviews with indigenous leaders, community members, NGO, State and donor agency representatives; and written documents, including project reports, evaluations, planning exercises, correspondence and workshop, meeting and Assembly minutes.

Conceiving the process as a dynamic discursive battlefield implied the use of a particular set of analytical tools that allows us to unravel changing power relations and negotiations between partnership actors, the emergence of particularly relevant discourses, and the role of each actor in introducing, using or contesting discursive elements, as well as the consequences of discursive shifts in shaping the evolution of the process. Our narration of the 'story' of Matavén makes flexible use of the scheme proposed by Adger et al. (2001), which identifies three elements: (1) regularities in expressions that identify discourses; (2) the actors producing, reproducing and transforming discourses; and (3) social impacts and policy outcomes. In this research, actors - particularly indigenous representatives and the relationships between them were the central units of analysis. As a further analytical device, special attention was given to the gaps between 'formal' and 'informal' knowledge in line with recent trends in the anthropology of development (Bebbington and Kothari 2007; McNamara and Morse 2004). Informal knowledge was understood as "practical and political knowledge on the details of implementation, effects and impacts of project officials, staff, etc. (...) frequently invisible to distant actors and also frequently kept invisible by those who posses it" (Van der Glas et al. 2007, p.2-3). Incorporating informal knowledge was necessary for the analysis of discourse negotiations and their practical effects.

\section{The Three Phases of the Matavén Framing Process}

\author{
Matavén: 'Heart of Health'-Framing for Partner \\ Recruitment (1998-1999)
}

In order to generate a multi-actor collaborative initiative that would result in territorial protection, the Etnollano Foundation recruited partner support by developing strategic representations of the Matavén territory and its sociocultural dynamics, as well as framing 'problems' and 'solutions.' Framing reflected a clear orientation towards national and international organizations with environmental and sustainable development objectives, which endorse global discourses on community-based and participatory 
approaches to conservation and development (Ulloa 2004) and constitutional mandates on indigenous peoples' rights and the social dimension of environmental protection. Framing was aimed at convincing actors of the potential of the Matavén initiative for true collaborative engagement with indigenous peoples, and of the positive effect that territorial rights over the central area of Matavén would have on local livelihoods and the conservation of forest ecosystems.

Project emphasis on culture, conservation, food security and livelihoods thus shaped the discourses underlying territorial claims. The central area started to be referred to as the 'Heart of Health' in publications and discussions between Etnollano and local leaders (Loboguerrero et al. 2000). Despite the previous lack of common identities based on ethnicity or territory, Matavén itself was presented as one multi-ethnic territory, the ancestral home of six ethnic groups. It was a 'belt of resguardos' (see Fig. 1) surrounding the common 'Heart,' which acted as the common spatial reference that united all groups who depended on its resources for survival.

Further, "multiculturalism" was a key component in representations of Matavén. United under a common territory, different ethnicities and settlement histories were strategically framed as 'cultural diversity,' presented as an asset for sustainability and conservation.

"Each one of these cultures has valuable knowledge about their environment, natural resources, climate seasons, and ecological behaviors (...). The diverse cultural particularities as a whole allow to project the region's global development from different perspectives and an array of experimental alternatives, founded on the daily reality of those who historically have known how to sustainably manage the environment" (Loboguerrero 2000, p. 29, translation by the authors).

The concept of 'Heart of Health' and the emphasis on cultural diversity depict local communities as bearers of traditional ecological knowledge and practices. Further, such framings assume a historical connection to this territory, despite the different and relatively recent settlement histories of communities in this area (Loboguerrero et al. 2000).

"Definitively, the Matavén Forest is the Heart of Health: the health of the people who live in the surrounding belt of resguardos, because there are the seeds to the reproduction of animal and plant resources needed for food security for the future generations; the health of their cultures, because they have been constructed based on the knowledge of its natural life; the health of its ecosystems, because on its biodiversity depends the future of one of the few transitional forests between the Orinoquia and Amazonia left in Colombia, possibly the only one with these characteristics" (Loboguerrero et al. 2000, p. 16; translation by the authors).

Geographically and environmentally, framings emphasized the area's uniqueness as the transitional zone between the eastern Orinoquia savannahs and the Amazon forested watershed. Given its transitional character, spatial heterogeneity and ecological and biological diversity are central in its descriptions, despite the lack of assessments of biodiversity and endemism levels at the moment (Mora et al. 2002). A key component of the framing strategy was to present the idea of titling the central area as a 'local request,' based on indigenous people's realization of the importance of its conservation. In this way, the process became a rare case in which, by local initiative, protected area status was requested for an indigenous territory. A first official request to the national government that the central area be given to them as a conservation zone under the ownership and management of an association of the 16 surrounding resguardos was presented in October 1998 by a group of indigenous leaders and promoters of Matavén (Loboguerrero 2000).

The Etnollano Foundation's framing strategy proved to be extremely successful, a clear example of a strategic translation of local realities into contemporary global discourses on indigenous peoples and conservation, conducted by an NGO. The strategy met no resistance on the part of indigenous leaders. A series of factors contributed to this uncontested discourse construction. First, with no other 'conservation and development' actors in the area, successful mobilization of territorial claims depended on Etnollano's support. Thus, it was clear to indigenous leaders that the accomplishment of territorial protection and institutional involvement depended on 'peaceful' relations with this NGO. The Foundation had been in the area for more than ten years, and had shown the financial and technical capacity to sustain both local projects and to attract international funding and strategic national partners. Etnollano's own discursive emphasis on community participation and traditional ecological knowledge and practices had proven to be a key factor in its success among donors and government. Thus, the Foundation's idea to situate territorial claims in terms of conservation and tradition was broadly supported as a means to ensure the goal of territorial protection, while also opening future possibilities of attracting projects and donor support.

The particularities of indigenous representation also played a role in support to conservation-oriented framings. The Foundation created Associations of Health Promoters. These consisted of young community leaders, many of 
whom became articulate in the global language of 'conservation and development' and familiar with the strategies used in multi-scale collaborative processes. Initially they represented 'the indigenous counterpart' which legitimized Etnollano's claims of an indigenous conservation initiative.

As the process grew from communities to 'territory' and incorporated new governmental actors, indigenous representation also expanded. Health promoters were joined by Cabildo or council governors (resguardos' legal authorities), and traditional leaders such as community captains and teachers. Cabildo governors became particularly influential in partnership discussions. Unlike health promoters, Cabildos were political leaders and had little previous experience in community-based NGO work. They were suspicious of the non-indigenous partner's intentions and emphasized - besides territorial protection - the issue of creating a representative indigenous organization for Selva de Matavén. Despite shifts in indigenous representation and the emergence of political discussions, conservation and tradition continued to be indispensable to the primary goal of territorial titling.

Thus, leaders joined Etnollano in granting 'local' legitimacy to conservationist discourses. The voices of elders were important for the future organization and framed the organizational initiative by incorporating 'traditional' wisdom on nature and culture, as the following pronouncement by Piaroa chief Roberto Pulido illustrates:

"Our Mother Forest is bearer of the existence of our social life. They (the 'whites') have divided our land with limits, breaking our communication and our universe with Mother Nature (...). The government should approve our petitions over the Great Ancestral Territory of the Matavén Forest, as we have lived from generation to generation, respecting our cultural heritage and its rules (...). Disrespecting traditional rules weakens our wisdom and threatens our life and biodiversity and the ecosystem. We, the Chiefs, fight to protect Mother Nature and give life to our nature and also to give courage to our leaders who fight constantly and confront the violence that is present in our Orinoco borderlands."

(Piaroa Chief, speech December 1999, simultaneous translation from Piaroa to Spanish)

As an outcome of this first discursive phase, partner recruitment resulted in a very strong and diverse set of actors representing different scales of government and civil society, with different functions and interests. The Matavén Group, later Institutional Support Group (GIA), was formed in 1998 in order to "coordinate efforts for the creation of the new resguardo and of an indigenous government to administer it" (Etnollano-GEF 2005, p. 13). Its members included, among others, the National Parks Unit, the National Alternative Development Plan (PNDA/Plante; the governmental agency responsible for manual coca eradication, promotion of alternative crops and sustainable rural development), the Organization of Amazonian Indigenous Peoples of Colombia (OPIAC), the National Indigenous Organization of Colombia (ONIC), the Colombian Institute for Agrarian Reform (INCORA), ${ }^{4}$ the Departmental Government of Vichada and the Etnollano Foundation.

Consistent with this, territorial protection implied the support for participatory decision-making among communities and partners about the best form of legal tenure, as well as the best management scheme for the area. PNDA/ Plante, the National Parks Unit and Etnollano supported local workshops and meetings, consultations with external experts and inter-partner discussions, as a result of which, by the end of 2000, indigenous leaders had decided to request INCORA to grant a common-use resguardo as a legal protection category for the central forest. In a parallel manner, an organization integrating the 16 resguardos was being formed, which, as agreed between indigenous leaders and non-indigenous partners, aimed at becoming an Association of Traditional Indigenous Authorities (AATI), legally recognized as an indigenous public authority in Decree 1088 of 1993. Furthermore, besides supporting the titling process, partners worked in community-based natural resource management projects and sustainable production. International donor support enabled all national partners' activities. Donors included the Inter-American Development Bank, the Spanish Agency for International Cooperation and the Royal Dutch Embassy, all of whom justified support to Matavén as part of their environmental programs and situated Matavén within their environmental agenda.

Discursive Shifts Towards a Greater Emphasis on Indigenous Organization and Self-Government (2000-2002)

The years that followed initial partner recruitment were characterized by the presence of multiple and diverse supporting organizations aiming at two overarching objectives: the legal protection of the central area and the formation of a new form of administration for the unified territory. Both objectives were achieved with the creation of the Association of Cabildos and Traditional Authorities of Matavén (ACATISEMA) in 2001 and the legal recognition of the Great Resguardo of Selva de Matavén in June 2003. ACATISEMA can be conceived both as a central actor in partnership discourse negotiation and implementation, and as a process of political reorganization and transformations

\footnotetext{
${ }^{4}$ Now the Colombian Institute for Rural Development (INCODER), the main government body for rural development.
} 
in local governance, while the legal recognition of the Great Resguardo of Selva de Matavén can be conceived as the outcome of a process of 'indigenous political re-organization' (Nagel and Snipp 1993). These processes correspond with the dynamic negotiations of discourses and activities that took place during these years. Contrary to the premeditated and uncontested construction of framings for partner recruitment in the first years of the Matavén initiative, the introduction and strategic use of discursive elements during this stage occurred in an interaction between the micro-politics of partnership practice and donor-oriented framings. Negotiations were marked by the increasing importance of a process of indigenous political organization and by efforts to reconcile interests despite conflicts between ACATISEMA and nonindigenous partners over project control. Thus, the incorporation of new discursive elements responded, on the one hand, to negotiated strategic framings that would ensure donor support to the process. On the other hand, actors' success in reframing discourses was proportional to the perceived benefits that particular new discursive elements would bring to the different actors within the partnership, particularly to the increasingly influential indigenous organization.

Using their position as legal representatives of local communities and taking advantage of official commitments to 'participation' and 'self-determination,' ACATISEMA leaders were able to claim a central role and to gain negotiating power among the group of decisionmakers. As a result, the partners' actions increasingly focused on support to ACATISEMA's functions as indigenous government.

Greater emphasis on indigenous political organization was not only a result of ACATISEMA's successful negotiation strategies and consequent shifts in power balances, but also found support in the adoption of the UN Declaration on the Rights of Indigenous Peoples in 2007. Throughout the years, partnership discourses shifted away from 'conservation' and 'tradition,' and progressively made room for 'autonomy,' adopting notions such as 'organizational strength' and 'self-government' as project components and strategies. Similarly, emphasis on the community level gave way to a 'territorial' perspective, highlighting territorial autonomy, protection against external threats and consolidation of territorial government. In no apparent contradiction, discourses of conservation and traditional knowledge/practices persisted within this general discursive shift, elements of which could be incorporated strategically in project documents and leaders' public speeches. This process can be illustrated through two major projects initiated under the Matavén initiative: the PNDA/ Plante 'Project of Social Agreements' implemented in 2000 (refered to as the 'PNDA/Plante project' below) and the GEF/World Bank Conservation and Sustainable Development project between 2001 and 2004.
The PNDA/Plante Project: Towards a More Political Understanding of 'Self-Government'

The PNDA/Plante project (2000) was the first aimed directly at strengthening the role of indigenous authorities, and initiated discursive shifts towards a more 'political' understanding of the Matavén initiative and set the tone for later partnership discussions. Its approach to project administration favored direct implementation by local leaders, for which an Indigenous Operative Committee was created, and focused on the consolidation of a Matavén-wide indigenous organization, which resulted in the decision to create an AATI. From then on, 'organizational strength' became a necessary project component, and partners' support for an emerging form of authority became as important as territorial protection. Further, the project stimulated a shift in interpretations of 'self-government.' Despite talks on 'self-government' in meetings and partnership agendas since 1999, the concept had been generally understood as a condition for (co-)management of the central area (Matavén Group Meeting minutes, 5 August 1999). With discussions of an AATI under way, 'selfgovernment' started to be interpreted as legally recognized indigenous authorities whose consolidation should aim at greater 'autonomy' and 'self-determination.'

Active participation of the National Indigenous Organization of Colombia (ONIC) and the Organization of Amazonian Indigenous Peoples of Colombia (OPIAC) contributed to this re-interpretation and a heightened political tone in partnership decision-making arenas. Such inputs were generally made in the midst of negotiations over project contents and administration, gaining strength in moments of conflict. Thus, indigenous bargaining power increased as ONIC and OPIAC constantly highlighted the need to protect indigenous autonomy and prevent 'imperialist' interventions, and made use of accusations of top-down approaches, 'hidden agendas' or monopoly over administrative and budget management decisions. Conflicts of this sort were particularly relevant for the National Parks Unit, often accused of wanting to impose a National Park and of being an agent of the Colombian state's "militaristic and neo-liberal" policies.

Two years after the official start of the partnership process, the role of indigenous leaders in the partnership had gone beyond 'participation' and 'representation.' Indigenous claims were now part of a process of political organization occurring in a parallel and interconnected manner to the Matavén partnership process.

\section{The GEF/World Bank Project: A Shift towards 'Organizational Strength' in Project Framing and Practice}

Although the local indigenous association ACATISEMA was now central to the partnership process, and budgets 
were being redirected to support the organization's needs, official framings in project documents and publications were hesitant to place the political organization process at the core of the Matavén initiative. The GEF/World Bank project (2001-2004) implemented by Etnollano provides a good example of this interplay between project framings and the occurrence of discursive shifts in practice.

Official project objectives were described in terms of biodiversity conservation, community participation and indigenous tradition. Its main objective was to "support indigenous communities in the Matavén Forest in the sustainable management and conservation of the region's biodiversity, contributing to the improvement of quality of life and the preservation of cultural and natural heritage" (GEF 2001). Concepts of indigenous autonomy, selfgovernment and articulation with the nation-state were not included in the project's objectives, expected results or activities. Instead, emphasis was put on the technical and legal aspects of territorial management and planning, with support for 'community leaders' situated within broader environmental management and conservation goals (GEF 2001). Despite this focus on conservation and communities, specific objectives and activities-which were adjusted with leaders during the first years of implementationemphasized the role of leaders and authorities as recipients of training, generators of community-level processes and representatives for territorial management decisions. Indeed, in the course of project implementation, adjustments in official project contents became a necessary outcome of indigenous leaders' negotiating power. For instance, in an act that ensured Etnollano's access to the field and the political viability of the GEF/World Bank project, NGO directives adjusted the initial project budget to redirect USD 6,000 ( $20 \%$ of total project budget) to "support the strengthening of ACATISEMA's Coordinating Committee" (Assembly minutes, September 2001) through a component of 'organizational strength.'

"In the beginning, the environmental debate was important among leaders. After that (1999-2001), 'the political' became more important and all the discussions were about the organization and its politics. That is why we had to adapt to these circumstances and make more emphasis on this in the project. (...) This doesn't depend on us...."

(Etnollano co-director, personal interview, 22 June, 2007, Spanish)

A different view questions these modifications, based on a lack of institutional capacity and the reliance on a selected group of leaders as representatives of 'indigenous priorities:'

"We as 'white' practitioners have the 'Syndrome of the Gods of Olympus.' We think we can do it all (...)
Etnollano redirected its resources towards so-called 'organizational strengthening' of 13 guys with no representativeness or legitimacy. ${ }^{5}$ Partners in Matavén can say that they shifted actions to organizational strengthening because it was a local priority. Well of course it becomes a priority if they're only working through these 13 members of the organization... they're going to say that's what you have to do!"

(Former National Parks Unit/ GAIA Foundation professional, 15 June, 2007, Spanish)

The use of 'organizational strength' in project discourse was thus a way of formalizing the support that leaders had negotiated 'on the ground' as a clear consequence of shifts in power balances. Beyond the contested reasons for its inclusion as a project component, direct support for an organizational process in the GEF/World Bank Conservation and Sustainable Development project signaled a discursive shift regarding what the Matavén process was about. In contrast to the (apolitical) main objective of the GEF/World Bank project, according to an Etnollano co-director:

"The project prepared ACATISEMA to exercise its role as self-government, its social and political functions and the historical role they were playing."

(Etnollano Co-director, written interview, July of 2007, Spanish)

As with the PNDA/Plante project, the initial years of the GEF/World Bank project showed a heightened political tone in project negotiations, with the Etnollano Foundation sometimes being accused of top-down agendas. At the time, indigenous leaders were suspicious of the World Bank's intentions, given its well-known support of neo-liberal reforms and the privatization of natural resources which were seen as counterproductive to indigenous claims for territorial autonomy and self-government. The resulting discursive shifts in the Matavén partnership illustrate the flexible and dynamic nature of discourses, which is also reflected in the variety of ways in which this process is defined in public speeches and documents. In general, there was a difference between indigenous leaders' framings and those of non-indigenous partners.

Non-indigenous partners generally defined the process according to the nature of their own support and the specific projects through which they worked. Thus, the Institutional Support Group (GIA) meeting minutes in early 1999 defined it as a 'Process of legal protection of the Matavén Forest,' while the Plante project defined it as a

\footnotetext{
${ }^{5}$ Refers to the 12 members of ACATISEMA's Coordinating Committee and its General Coordinator.
} 
'Process of Social Agreements' and later GIA meeting minutes simply as a 'Process of Conservation of the Matavén Forest' (6 November 2000) or, after the start of the GEF/World Bank project, a 'Process of Conservation and Development' (10 September 2001).

On the other hand, in local political arenas such as Indigenous General Assemblies, indigenous leaders presented the multi-actor partnership as a means to ensure support for an indigenous agenda which should lead to adjustments in partners' institutional interests. The process was invariably framed by leaders as one of indigenous mobilization for the protection of collective rights, particularly the rights to territory, with increasing emphasis on political organization and self-government as ACATISEMA gained strength.

Emphasis on indigenous political organizing did not imply the disappearance of conservationist discourses in leaders' speeches or in documents endorsed by ACATISEMA. Given that donors and non-indigenous partners justified their involvement with the process in terms of environmental objectives, indigenous leaders realized early on that financial and technical support for ACATISEMA was made possible by framing the Matavén process in environmentalist terms. Further, the influence of donors and practitioners in designing Assembly agendas and their presence during meetings guaranteed that official (environmental) project objectives and components were addressed and endorsed by ACATISEMA leaders. As an influential member of ACATISEMA stated:

Because the Matavén Forest now has to finance itself, not wait until other institutions bring the money. For that, it will sell its image at the international level as an area of conservation and protection of natural resources. With taking care and conserving, several agencies will finance us, and with that we can sustain ourselves. But in order for that to happen we have to design the development projects of the Matavén Forest.

(First ACATISEMA General Coordinator, Assembly 2007, Spanish, own emphasis)

As this quote illustrates, reliance on environmental discourses continues, and leaders are increasingly open to communities about the strategic importance of having a conservationist image in order to guarantee funds to cover a broader set of local issues.

Towards an Amalgamation of Discourses: Reconciling Interests through 'Territorial Ordering' (Late 2002-2004)

In a successful attempt to provide a conceptual common ground for environmental and political agendas and give discursive coherence to multi-actor collaboration, the National Parks Unit suggested in 2001 the use of 'territorial ordering' as a conceptual frame for the Matavén process. In a meeting in November 2002, the members of the Interinstitutional Support Group (GIA) agreed on a strategy to advance a Territorial Ordering Plan that would “...strengthen grassroots organizations and the indigenous Association, and...put into practice diverse strategies that guarantee its conservation in the short, medium and long term" (GIA meeting minutes, November 10, 2002; translation by the authors).

Territorial ordering is a broad concept that allowed flexibility in the definition of project objectives and activities, enabling actors in the partnership to reconcile project aims with their own specific interests. Conceived since the Political Constitution of 1991 as a process of territorial planning based on the incorporation of sociocultural, political, economic and environmental variables (Borja 1998), the concept was used in indigenous contexts as an instrument of participatory planning for selfdetermination and articulation with the state (Echeverri 2000; Franky 2001) and could include cultural strengthening, self-government, territorial protection, sustainable development, natural resource management and administrative articulation with local and regional governments, among others.

Besides facilitating negotiations within the partnership, territorial ordering was considered a strategic tool for articulation with municipal and national governments. Municipalities were required to have territorial ordering plans, which should recognize cultural and environmental diversity within them and aim to integrate municipal plans with indigenous territorial conceptions and forms of management. Therefore, ordering at the level of the resguardo was thought of as a way to formalize recognition of indigenous environmental practices, 'visions of development' and forms of organization by municipal governments. This recognition was at the core of ACATISEMA's consolidation as indigenous government, given that effective negotiation of public budget allocations and health and education services with state actors constituted its most challenging and important function. At a symbolic level, by using the language of the Constitution-indigenous territorial autonomy, multicultural Nation-building and recognition of collective civil rights - territorial ordering repositioned the Matavén process within a historical and political perspective.

As noted above, the National Parks Unit took a leading role in the introduction of 'territorial ordering' in partnership discourse which aided adoption of this concept. The National Parks Unit was very influential in the Matavén partnership in the period between 1999 and 2004, as its discourse and policies and political support were attractive 
to both indigenous and non-indigenous partners. As the National Public Environmental authority, this institution gave legitimacy to the partnership in relation to the Colombian State, symbolizing its concurrence with 'environmental governance' trends and respect for public policies and institutions, as well as providing a link to high-level government decision-making, which made it a strong lobbying partner for the titling process. Thus, this institution wielded important clout in partnership dynamics influencing the reframing of the process in terms of territorial ordering.

In practice, the broad and flexible character of territorial ordering made it subject to strategic interpretations in project documents, generally targeting donors' interests in conservation and natural resource management without excluding 'organizational strength.' Thus, despite symbolic political implications its translation into project discourse revolved around natural resource management and planning. Similarly, indigenous authorities' explanations of territorial ordering to communities combined technical, conservation-oriented emphasis with assumed political benefits. In the following speech, an ACATISEMA leader explains the political importance of territorial ordering to an Indigenous Assembly:

We are making our Territorial Ordering Plan (TOP), our Natural Resource Management Plan. We are contributing oxygen. That's why the Plans of the Matavén Forest should be included in Cumaribo's ${ }^{6}$ TOP, so that we are recognized as an 'area of special ecological importance,' inserted in the national environmental system. This is key because the TOP is the first step towards becoming an autonomous Indigenous Territorial Entity (ETI). ${ }^{7}$ When that happens we will be autonomous and "walk on our own.'

(ACATISEMA leader, Eleventh General Assembly, May 2007, Spanish)

Towards the end of the period 1998-2004 it became clear that discussions of territorial ordering shifted away from strict 'conservation and development' led by nonindigenous partners, towards increased centrality of a process of indigenous political organization with ACATISEMA at its core. Basically, it became a means to enhance the Association's capacity to exercise more control over project decision-making and administration. Since the end of GEF/World Bank project in 2004, partnerships with non-

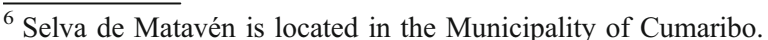

${ }^{7}$ According to the Constitution of 1991, further legislation (yet to be developed) should define the norms and procedure so that indigenous territories become territorial entities at the level of departments and municipalities.
}

indigenous organizations in Matavén have been limited to financial and administrative support, with project decisionmaking and implementation in the hands of ACATISEMA and a group of consultants.

In 2004 ACATISEMA was able to take direct control of a one million euro, 3-year project funded by the Dutch Embassy. ACATISEMA's ability to become the implementing agency for a project of such magnitude was, to a great extent, based on the strategic use of discourses of indigenous autonomy and the notion of 'territorial ordering.' The 'Amazonic Program' was officially titled 'Strengthening of Community Autonomy for Life, Territory and the Environment,' and its three main components were territorial ordering, governance and sustainable development. Such a shift in project discourse, now embracing concepts of 'governance' and 'autonomy,' surely contributed to the Dutch Embassy's decision to support direct project implementation by ACATISEMA. The latter, in turn, made use of these discourses to design a project whose central objective was "To enhance the organizational strength of ACATISEMA as articulating an axis of territorial ordering and governance in the unified resguardo of Selva de Matavén" (Programa Amazónico 2004, p. 17, translation by the authors).

\section{Discussion}

It is clear that the framing of discourse is not simply a reflection of unequal power relations, but of negotiation and compromise. At the time of partner recruitment for the Matavén initiative, emphasis on conservation, indigenous tradition and community participation was a compromise between the NGO Etnollano and indigenous leaders. As Li (1999: 298) asserts, "as an agreement between two parties, a compromise assumes that agency is distributed, if unevenly: both sides have a 'power to.' It also assumes a level of conscious knowledge and understanding of what is being gained and given up." The use of such framings ensured multi-scale recruitment for the territorial titling process and further project support, while meeting no evident 'costs.' Framings did not explicitly embrace indigenous political and territorial organizing, but they also did not exclude possibilities for its future negotiation. In fact, while conservationist framings were gaining strength in publications and project proposals, there was a steady increase of leaders' negotiating power which slowly redirected the partnership agenda towards supporting the process of indigenous political organization.

These shifts in the partnership agenda owed much to indigenous leaders' use of appeals to autonomy and selfdetermination in the context of project negotiations. However, the potential of these discursive resources to 
effectively translate into partnership shifts-both in discourse and in practice - could hardly have been met had there not been conditions 'on the ground' that favored shifts in power relations. The fact that leaders were the focus of the PNDA/Plante project and were in charge of project administration, strategic interventions of the indigenous organizations ONIC and OPIAC in project negotiations, and the very real possibilities of becoming an Association of Traditional Indigenous Authorities (AATI), generated a favorable environment for a reinterpretation of 'selfgovernment' which implied greater decision-making power for indigenous leaders and the recognition of an ongoing indigenous political process.

In general, repositioning of actors in decision-making arenas and non-formal reorientation of project activities preceded shifts in official project framings. As the GEF/ World Bank project illustrates, shifts in official project discourse occurred gradually and in ways that did not threaten the interests of the different parties-donors, intermediary NGOs and the indigenous Association. The process of readjusting the GEF/World Bank project 'along the way' was one of continuous compromise-seeking: Etnollano had to respond to the pressure of the local indigenous association ACATISEMA to redirect project funds to its own 'organizational strength.' In order to do so, justifications had to be made in official project documents as well as in the NGO's own explanatory narratives, which carefully avoided giving up 'conservation,' 'communitybased development' and 'tradition' as framings that guaranteed donor support.

Official discourses gave coherence to projects and partnership arrangements, and ensured partner and donor support. As such, they were a fundamental part of the partnership's 'structure.' However, as McDaniel (2002: 371) asserts, structures in development interventions are "challenged and often transcended by NGOs and grassroots indigenous organizations in confronting donor agendas, project budgets (...) and transforming internal political organization." In the case of Matavén, formal discourses became relevant in partnership practice only inasmuch as they could be used by actors in the pursuit of particular aims. In most cases, they were simply 'transcended' and did not constitute constraints, which explains the 'peaceful' coexistence of different definitions and interpretations of the Matavén process, as well as the continued endorsement of 'conservation' by ACATISEMA. The latter had few costs to the Association besides having to justify the implementation of community-based conservation initiatives to local constituencies.

Although official partnership discourses left broad space for maneuvering in the field, their effectiveness in ensuring donor support and publicly positioning Matavén as a successful multi-actor initiative for conservation in indige- nous territories, required some degree of coherence between discourse and practice. As discussed above, partners had to adjust project framings to ensure conceptual coherence with ongoing shifts towards greater focus on supporting ACATISEMA while guaranteeing their continued match with global donor interests. Further, they had to provide explanatory narratives to realities in the field, while also allowing space for maneuver and multiple interpretations. 'Territorial ordering' met all these conditions. While its adoption was partly a consequence of the National Parks Unit's influence as the sole representative of the National government, the concept did not perpetuate a static power (im)balance, but instead provided an arena for a wide variety of interests and actions to be negotiated in practice. As such, the territorial ordering concept reflected the amalgamation of various discourses employed within the Matavén partnership, combining global conservation and sustainable development discourses with indigenous claims for territorial autonomy and self-governance.

\section{Conclusion}

This analysis of the Matavén initiatives in the Colombian Amazon reveals that partnership discourses reflect both power relations and compromises. Their development, interpretation and successful mobilization occur within the micro-politics of multi-sector partnerships, constituting a dynamic process. Under shifting power balances, actors in the partnership may strategically incorporate or transcend elements of global discourses at particular moments for a variety of purposes. In the Matavén initiative this discursive process occurred in three phases. The first NGO-initiated phase (1998-1999), which focused on partner recruitment, strategically combined indigenous discourses on territoriality with global discourses on indigenous ecological knowledge and practices, community participation and biodiversity conservation. Without abandoning the latter framings, the second phase (2000-2002) witnessed a greater emphasis on indigenous organization - both political and territorial - with increasing bargaining power for local (ACATISEMA), regional (OPIAC) and national (ONIC) indigenous organizations. This phase resulted in discursive shifts towards a more political interpretation of 'self-government' and a greater emphasis on 'organizational strength' as reflected in the PNDA/Plante and GEF/World Bank projects that were initiated in 2000 and 2001, respectively. In the third phase (late 2002-2004) the various discourses amalgamated in the 'territorial ordering' concept, which incorporates notions of cultural strengthening, self-government, territorial protection, sustainable development, natural resource management and administrative articulation with local and regional governments. 
The flexible use of the various framings shows that discourses, far from being hegemonic and excluding politics, are consciously used to remake politics, including new political entities. As such, they constitute resources in the pursuit of individual actors' interests and a middle ground between structure and agency in forest partnerships. While they are part of the structure of international 'conservation and development,' their translation into practice occurs in an arena of negotiation among partnership actors with diverse interests and is therefore challenged and contested. Discourses thus allow actors to exert agency and adjust structures in their favor. As the Matavén case has shown, this is possible without posing threats to the participation of other partnership actors or constituting constraints for potential shifts in implementation. Effective outcomes were largely dependent on the context in which discourses were used, the meaning(s) attached to particular concepts, and the objectives being sought.

Beyond global 'conservation' vs. local 'indigenous selfdetermination,' discourses represent compromises in which agency is redistributed among actors. As the Matavén partnership process has shown, this results in discursive shifts through which power balances are contested and local benefits and political claims can be negotiated without jeopardizing the continuity of the partnership. The underlying framing process thus turns a multi-sector partnership into a dynamic discursive battlefield in which actors strategically employ and combine discourses to negotiate objectives and actions.

Acknowledgements The authors wish to thank two anonymous referees for constructive comments to an earlier draft of this paper.

Open Access This article is distributed under the terms of the Creative Commons Attribution Noncommercial License which permits any noncommercial use, distribution, and reproduction in any medium, provided the original author(s) and source are credited.

\section{References}

Adger, W. N., Benjaminsen, T. A., Brown, K., and Svarstad, H. (2001). Advancing a Political Ecology of Global Environmental Discourses. Development and Change 32: 681-715.

Andolina, R., Radcliff, S., and Laurie, N. (2005). Development and Culture: Transnational Identity Making in Bolivia. Political Geography 24: 678-702.

Assies, W. (2000). Indigenous Peoples and Reform of the State in Latin America. In Assies, W., van de Haar, G., and Hoekema, A. H. (eds.), The Challenge of Diversity: Indigenous Peoples and Reform of the State in Latin America. Thela Thesis, Amsterdam, pp. 3-21.

Bebbington, A., and Kothari, U. (2007). Network Ethnographies: Life, Livelihood and Institutions in Transnational Development Relationships. Paper presented at NGO Study Group Seminar 'Ethnography of NGOs: Understanding Organizational Processes',
Oxford, 28 April 2004, http://www.intrac.org/docs/Bebbington Kothari.pdf (accessed August 18 2008).

Borja, M. (1998). Estado, Sociedad y Ordenamiento Territorial en Colombia. CEREC-IEPRI, Universidad Nacional de Colombia, Bogotá.

Brackelaire, V. (2005). Inventario de Iniciativas Socioambientales en la Amazonía del Noroeste. Brasil, Colombia, Venezuela (19942005). Fundación GAIA Amazonas, Bogotá.

Brook, M. M. (2005). Re-scaling the Commons: Miskitu Indians, Forest Commodities, and Transnational Development Networks. $\mathrm{PhD}$ thesis, University of Texas.

Brosius, J. P. (1999). Analyses and Interventions: Anthropological Engagements with Environmentalism. Current Anthropology 40: 3277-309.

Bryant, R. L. (2002). Non-governmental Organizations and Governmentality: 'Consuming' Biodiversity and Indigenous People in the Philippines. Political Studies 50: 2268-292.

Bryant, R. L., and Bailey, S. (1997). Third World Political Ecology. Routledge, London.

Chapin, M. (2004). A Challenge to Conservationists. World Watch Nov./Dec.: 17-31.

Chernela, J. (2005). The Politics of Mediation: Local-Global Interactions in the Central Amazon of Brazil. American Anthropologist 107: 4620-31.

Colchester, M. (1996). Beyond 'Participation': Indigenous Peoples, Biological Diversity Conservation and Protected Area Management. Unasylva/FAO 47(186).

Colchester, M., Apte, T., Laforge, M., Mandondo, A., and Pathak, N. (2003). Bridging the Gap: Communities, Forests and International Networks. Synthesis Report of the Project 'Learning Lessons from International Community Forestry Networks', CIFOR Occasional Paper No. 41. Centre for International Forestry Research (CIFOR), Bogor.

Conklin, B. (1997). Body Paints, Feathers and VCRs: Aesthetics and Authenticity in Amazonian activism. American Ethnologist 24: 41711-737.

Dove, M. (2006). Indigenous People and Environmental Politics. Annual Review of Anthropology 35: 191-208.

Dryzek, J. (2005). The Politics of the Earth. Environmental Discourses. Oxford University Press, Oxford.

Echeverri, J. A. (2000). Reflexiones sobre el Concepto de Territorio y Ordenamiento Territorial Indígena. In Vieco, J., Franky, C., and Echeverri, J. A. (eds.), Territorialidad Índígena y Ordenamiento en la Amazonía. Universidad Nacional de Colombia-COAMA, Bogotá, pp. 173-182.

Escobar, A. (1998). Whose Knowledge, Whose Nature? Biodiversity, Conservation and the Political Ecology of Social Movements. Journal of Political Ecology 5: 153-82.

Etnollano (2000). Conservación y Desarrollo Sostenible en la Selva de Matavén, Project draft. COL Matavén MSP, unpublished.

Etnollano-GEF (2005). Matavén-GEF. Un Proyecto, un Proceso, una Vivencia, Final Report 2001-2004. Etnollano-GEF-World Bank. http://www.etnollano.org (accessed 18 August 2008).

Fairhead, J., and Leach, M. (2003). Science, Society and Power: Environmental Knowledge and Policy in West Africa and the Caribbean. Cambridge University Press, Cambridge.

Finley-Brook, M. M. (2007). Impacts of Multi-Scale Partnerships on Miskitu Forest Governance in Nicaragua. In Ros-Tonen, M. A. F. (ed.), Partnerships in Sustainable Forest Resource Management: Learning from Latin America. CEDLA Latin America Studies 94. Brill, Leiden, pp. 207-227.

Fisher, L., Russell, V., and Ericson, J. (2005). Coalition Building for Conservation: Latin American Multi-Stakeholder Partnerships. In The Nature Conservation Agency, Protected Areas Conservation Coalitions: A Guide for Evaluation and Strengthening, Resources for Success Series 5. Arlington, Virginia: The Nature Conservation Agency, Arlington, pp. 11-23. 
Franky, C. (2001). Ordenamiento Territorial Indígena Amazónico: Aportes desde la Diversidad al Estado-Nación Colombiano. In Franky, C., and Zárate, C. (eds.), Imani Mundo. Estudios en la Amazonía Colombiana. Universidad Nacional de ColombiaIMANI, Bogotá.

GEF (2001). Conservation and Sustainable Development of the Matavén Forest, Project summary PDF-A, http://gefonline.org/ projectDetailsSQL.cfm?projID = 1020 (accessed 1 July 2007).

Glasbergen, P., Biermann, F., and Mol, A. P. J. (eds.), (2007). Partnerships, Governance and Sustainable Development. Reflections on Theory and Practice. Edward Elgar, Cheltenham.

Hajer, M. A. (1995). The Politics of Environmental Discourse. Ecological Modernization and the Policy Process. Oxford University Press, Oxford.

Hernández Camacho, J., Walschburger, T., Ortiz, R., and Hurtado, A. (1992). Unidades Biogeográficas de Colombia. In Halftter, E. (ed.), La Diversidad Biológica de Iberoamérica. Acta Zoológica Mexicana (special volume), pp. 175-190.

Instituto Colombiano de Reforma Agraria -INCORA (2003). Resolución No. 037 del 22 de Julio de 2003, por la cual se unifican bajo el nombre de Resguardo Indígena de la Selva de Matavén los 16 resguardos. INCORA, Bogotá.

Jackson, J., and Warren, K. B. (2005). Indigenous Movements in Latin America, 1992-2004: Controversies, Ironies, New Directions. Annual Review of Anthropology 34: 1549-573.

Li, T. (1999). Compromising Power: Development, Culture and Rule in Indonesia. Cultural Anthropology 14: 3295-322.

Loboguerrero, M. (2000). Conservación y Desarrollo en la Selva de Matavén. In Loboguerrero, M., Herrera, X., De Greiff, J., and Luque, A. (eds.), COAMA-Etnollano, Bogotá, pp. 27-49.

Loboguerrero, M., Herrera, X., De Greiff, J., and Luque, A. (eds.) (2000). Matavén. Selva Corazón de la Salud. COAMAEtnollano, Bogotá.

Martinez Cobo, J. (1986). Study of Discrimination against Indigenous Populations. UN Doc. E/CN.4/Sub.2/1986/7/Add.4.

McDaniel, J. (2002). Confronting the Structure of International Development: Political Agency and the Chiquitanos of Bolivia. Human Ecology 30: 3369-396.

McNamara, S. R. N., and Morse, S. (2004). Voices from the Aid Chain: The Personal Dynamics of Care. Social and Cultural Geography 5: 2253-270.

Mora, E., Ospino, H., Correa, H. D., and Luque, A. (2002). Proceso de Conservación en la Selva de Matavén. In Parques Nacionales de Colombia. Parques con la Gente II. Selección de Avances 2000-2001. Ministerio de Medio Ambiente-Unidad Administrativa Especial del Sistema de Parques Nacionales Naturales, Bogotá, pp. 151-160.

Mosse, D. (2004). Is Good Policy Unimplementable? Reflections on the Ethnography of Aid Policy and Practice. Development and Change 35: 4639-671.

Mosse, D. (2005). Cultivating Development. An Ethnography of Aid policy and Practice. Pluto, London.

Nagel, J., and Snipp, C. M. (1993). Ethnic Reorganization: American Indian Social, Economic, Political and Cultural Strategies for Survival. Ethic and Racial Studies 16: 2203-235.

Offen, K. (2003). The Territorial Turn: Making Black Territories in Pacific Colombia. Jounal of Latin American Geography 2: 143-73.

Perreault, T. (2001). Developing Identities: Indigenous Mobilization, Rural Livelihoods and Resource Access in Ecuadorian Amazon. Ecumene 8: 4381-413.

Perreault, T. (2003). Social Capital, Development and Indigenous Politics in Ecuadorian Amazonia. Geographical Review 93: 3328-349.

Programa Amazónico (2004). Memorandum de Valoración. Proyecto 'Fortalecimiento de la Autonomía Comunitaria en torno a Vida,
Territorio y Medio Ambiente en Sub-regiones Amazónicas', Doc. No. 10425, Programa Amazónico, Bogotá.

República de Colombia (1991). Constitución Política de Colombia 1991.

Rival, L. (2007). Alliances for Sustainable Forest Management: Lessons from the Ecuadorian Choco. In Ros-Tonen, M. A. F. (ed.), Partnerships in Sustainable Forest Resource Management: Learning from Latin America. CEDLA Latin America Studies 94. Brill, Leiden, pp. 37-62.

Rodríguez, G. (2004). La Función Ecológica de la Propiedad en la Ampliación, Reestructuración y Saneamiento de Resguardos Indígenas' In Londoño Toro, B. (ed.), Propiedad, Conflicto y Medio Ambiente. Centro Editorial de la Universidad del Rosario, Bogotá, pp. 109-114.

Rosendo, S. (2007). Partnerships across Scales: Lessons from Extractive Reserves in Brazilian Amazonia. In Ros-Tonen, M. A. F. (ed.), Partnerships in Sustainable Forest Resource Management: Learning from Latin America. CEDLA Latin America Studies 94. Brill, Leiden, pp. 229-253.

Ros-Tonen, M. A. F., Van den Hombergh, H., and Zoomers, E. B. (2007). Partnerships for Sustainable Forest and Tree Resource Management in Latin America: The New Road towards Successful Forest Governance? In Ros-Tonen, M. A. F. (ed.), Partnerships in Sustainable Forest Resource Management: Learning from Latin America. Brill, Leiden, pp. 3-35.

Ros-Tonen, M. A. F., Van Andel, T., Morsello, C., Otsuki, K., Rosendo, S., and Scholz, I. (2008). Forest-Related Partnerships in Brazilian Amazonia: There is More to Sustainable Forest Management than Reduced Impact Logging. Forest Ecology and Management 256: 1482-1497.

Scholz, I. (2005). Environmental Policy Cooperation among Organised Civil Society, National Public Actors and International Actors in the Brazilian Amazon. European Journal of Development Research 17: 4681-705.

Ulloa, A. (2004). La Construcción del Nativo Ecológico. Instituto Colombiano Antropología e Historia, Bogotá.

UNPFII Secretariat (2005). Engaging Indigenous Peoples in Governance Processes: International and Legal Policy Frameworks for Engagement. UN Workshop on Engaging the Marginalized: Partnerships between Indigenous Peoples, Governments and Civil Society, Brisbane, Australia, August 15, 2005, Background paper, http://www.un.org/esa/socdev/unpfii/documents/engage ment_backgaround_en.pdf (accessed 18 August 2008).

Van Cott, D. L. (2001). Explaining Ethnic Autonomy Regimes in Latin America. Studies in Comparative International Development 35: 430-58.

Van der Glas, M., Bebbington, A., and Zaal, F. (2007). Evaluative Research in Development NGOs: Lessons from the Study of Rural Development and Poverty Eradication Interventions. Paper presented at NGO Study Group Seminar 'Ethnography of NGOs: Understanding Organizational Processes', Oxford, 28 April 2004. http://www.intrac.org/docs/Glas_Bebbington_Zaal.pdf (accessed 18 August 2008).

Van der Hammen, M. C. (2003). The Indigenous Resguardos of Colombia: Their Contribution to Conservation and Sustainable Forest Use. IUCN-NL, Amsterdam.

Van den Hombergh, H. (2004). No Stone Unturned. Building Blocks of Environmentalist Power versus Transnational Industrial Forestry in Costa Rica. Latin America Research Series. Dutch University Press, Amsterdam.

Van den Hombergh, H. (2007). Partnership on Paper: Power Struggles and Strategic Framing around Industrial Forestry in Southern Costa Rica. In Ros-Tonen, M. A. F. (ed.) Partnerships in Sustainable Forest Resource Management: Learning from Latin America. CEDLA Latin America Studies 94. Brill, Leiden, pp. 85-105. 